\title{
The Effect of Cooperative Learning Techniques on Intermediate Iranian EFL Learners' Reading Comprehension and Reading Strategies
}

\author{
Neda Kord Ali Gurk \\ Dept. of English Language Teaching, Islamic Azad University, Shahr.e.qods \\ Science and Research Branch, Iran \\ E-mail: neda_kag@yahoo.com \\ Behdokht Mall-Amiri (Corresponding author) \\ Dept. of English Language, Islamic Azad University, Central Tehran Branch, Iran \\ E-mail: Beh.malamiri@iauctb.ac.ir
}

Received: Sep. 21, 2016 Accepted: Oct. 24, 2016 Published: November 1, 2016

doi:10.5296/jse.v6i4.10011 URL: http://dx.doi.org/10.5296/jse.v6i4.10011

\begin{abstract}
The purpose of this study was to investigate the effect of Cooperative Learning techniques on Intermediate Iranian EFL learners' reading comprehension, and reading strategies. In order to do this 90 Iranian EFL learners took, Preliminary English Test (PET), at the start for the researcher homogenize them regarding their general English proficiency. After that, 60 learners whose scores were one standard deviation above and below the mean were selected and were divided into 2groups; Experimental, and Control. Then their homogeneity regarding their reading comprehension was checked through the PET reading comprehension subtest. Afterwards, their reading strategies before the treatment were compared using MARSI questionnaire. During the twelve sessions of treatment the experimental group received the Cooperative Learning Techniques while working on their reading comprehension, and the control group, received traditional teaching without focus on CL techniques. In this study the researcher did not teach reading strategies to the learners. In order to investigate the result of the research a one way MANOVA sample test was used to see the effect of cooperative learning techniques on intermediate Iranian EFL learners' reading comprehension, and reading strategies, and the result has shown that cooperative learning techniques had a significant positive effect on intermediate Iranian EFL learners' reading comprehension, and reading strategies.
\end{abstract}


Keywords: Cooperation, Cooperative Learning Techniques, Reading comprehension, Reading strategies 


\section{Introduction}

Having the ability to comprehend L2 texts can make contribution to more effective learning of L2 since learners will be provided with an opportunity to be exposed to more input through reading and comprehending the L2 texts. Furthermore, as Jacobs, DuFon, \& Hong, (1994) maintain, the skill of effective reading comprehension can play an important role in making one's studies enjoyable, keeping oneself updated through reading the daily press and news.

A look at the literature on instruction of reading shows that different linguistics and psychology theories have provided the theoretical foundations for these courses. According to Langer and Allington (1992) the main developments of reading curriculum were inspired by British notions of primary instruction (for method) as well as religion (for content) and by scientific experiments (for theory) in late 1800. As Langer and Allington (1992) assert, the views putting emphasis on the individual learner as well as learner-centered instruction influenced reading. However, psychological research had provided the theoretical support for reading by the early 1900. Actually, the combined impacts of the developing scientific research base and the application of management principles to the organization of schools overshadowed the impact of the progressive reading educators. (Langer \& Allington, 1992).

A look at literature shows that the developments in $20^{\text {th }}$ century such as associationist and behaviorist psychology continued to shape reading research, curriculum and teaching all through the 1940's, 50's and 60's. In the meantime, reading was also impacted by studies and theory in language and concept development (e.g., Bloom, 1971; Inhelder \& Piaget, 1958), linguistics (e.g., Fries, 1963) and psycholinguistics (e.g. Goodman, 1967). The fields of sociolinguistics and language acquisition took on very important and influential role during the 1970's. This was followed by cognitive psychology and constructivist perspectives which influenced reading research. In fact, attention shifted toward the meaning construction that occurs during reading as well as toward the interactions between reader and text (Ur, 1996).

Considering the complex characteristics of reading as other skills, readers can make their reading more effective by using strategies to approach the reading tasks. Brown (2000) described strategies as particular methods used by an individual to approach a problem or task, modes of operation for accomplishing a specific objective, planned designs used to control and manipulate specific information. Brown believes that the strategies vary across the individuals (each person has access to a number of possible ways to solve a given problem, choosing one - or multiple in sequence - for a given problem). Strategies are very essential in providing the learners with an opportunity to develop their language competence. L2 learners have various kinds of language learning strategies at their disposal. According to Oxford (1990) language learning strategies are steps taken by learners to improve their own learning.

The learners' application of learning strategies is believed to be one of the essential factors contributing to successful language learning. Based on the results of the early L2 strategies studies conducted by researchers such as Rubin (1975), Stern (1975) and Naiman (1978), good L2 learners are strategic ones. Rubin (1975) asserts that effective L2 learners implicate themselves in all dimensions of language learning (e.g. affective, linguistic, and environmental). Generally, as Oxford \& Nyikos, (1989) have pointed out, good language 
learners make use of strategies more consciously, more purposefully, more appropriately, and more frequently compared to poor learners.

In recent decades, various kinds of strategies, in particular, reading strategies as well as their impact on L2 learning have drawn the attention of many scholars. For example, Mokhtari and Sheorey (2002) claim that students' familiarity with reading strategies can impact their reading comprehension positively. According to Brown (2000), strategies vary across the tasks that one approaches, constituting the very basic difference between strategies and styles. Moreover, as Keefe (1997) asserts, learning styles are considered as stable tendencies. These styles refer to the cognitive, affective, and physiological attributes which are rather stable indicators of the way in students perceive, interact with, and respond to the learning environment. Reading strategies refer to the plans for readers to solve problems encountered in constructing meaning from texts (Duffy, 1993). Such strategies are used by the reader to enhance reading comprehension and overcome comprehension failure. According to Salvin (1987) one of the important factors in EFL situation which can lead to the activation of readers' background knowledge is Cooperative Learning.

Based on Momtaz, and Garner (2010), during the past two decades, collaborative learning methods, and techniques (e.g. Collaborative Strategic Reading) have been widely used in ESL, and EFL setting. Various hypotheses, and theories support the use of cooperative learning in English as a foreign language (Abdullah, \& Jacobs, 2004). According to Davis (1999) community plays a central role in the process of "making meaning" (p.5), and also as Mirzaiee (2012) stated, according to Lantof (2006) social interaction is critical component of situated learning which makes learners more active in the process of "community of practice". As Davis states, in CL setting students see a variety of students in various stages of mastery of cognitive tasks, and peers provide support, and assistance to one another. Thus, the present study focused on teaching reading comprehension through cooperative learning techniques to find out if it has any significant effect on the EFL learners reading comprehension, and reading strategies.

\section{Review of Literature}

\subsection{Language Learning Strategies}

The definition given by Brown (2000) of strategies characterize them as particular methods used by an individual to approach a problem or task, modes of operation for accomplishing a specific objective, planned designs used to control and manipulate certain information. Brown claims that the strategies vary across the individual (each individual has multiple possible ways to solve a particular problem, and we choose one or several in sequence for a given problem). Strategies make important contributions to learners' ability to develop their language competence.

Generally, learners differ from each other in terms of the different types of cognitive characteristics namely language learning strategies. Oxford (1990) describes language learning strategies as steps taken by learners to improve their own learning. The application of learning strategies is deemed to be one of the essential factors contributing to successful language learning. Based on the findings of the early studies conducted on language learning strategies (e.g. Rubin 1975; Stern 1975; and Naiman, 1978) good language learners are strategic ones. 
According to Rubin (1975) good L2 learners implicate themselves actively in all dimensions of language learning including affective, linguistic, and environmental. Overall, as Oxford \& Nyikos (1989) assert good language learners use strategies more consciously, more purposefully, more appropriately, and more frequently compared to poor learners.

As Oxford (1990) asserts, language learning strategies are of great importance since they makes contribution to learners' self-directed participation which is crucial for the development of communicative competence, enhanced proficiency, and more self-confidence. Oxford believes that interaction among learners using meaningful, contextualized language is a requirement for communicative competence development. Language learning strategies enable students to take part actively in such authentic communication. Nunan (1998) emphasizes the significance of language learning strategies from awareness perspective, saying that being aware of what one is doing as well as the process used in learning will result in more effective learning. Consequently, researchers have recommended that instructing readers to use strategies need to be one of the first considerations in the reading classroom (Pressley \& EL-Dinary, 1992).

Interest in surveying language learning strategies began in the 1970s following the emergence of efforts to identify the features of good language learners (Davis, 2010). In particular, the studies conducted by Rubin (1975) and Stern (1975) had a crucial role in substantiating language learning strategies in both language classes and in natural environments. In recent year, different kinds of strategies such as reading strategies and their impact on L2 learning have been investigated by researchers. For example, Mokhtari and Sheorey (2002) claim that students' familiarity with reading strategies can have a positive effect on their reading comprehension. According to Brown (2000) strategies may vary across the activities a learner should do. This represents a very basic difference between strategies and styles. In addition, as Keefe (1997) discusses, learning styles are characterized as stable orientations which are manifested in the cognitive, affective, and physiological traits. They are relatively stable indicators of the way in which an individual perceives, engages in interaction with, and makes response to the learning environment.

According to Oxford (1990) there are some differences between learning styles and language learning strategies. For example, while one can rarely change his/her learning styles or personality traits, it is possible to change language learning strategies through formal instruction. Oxford asserts that strategy training provides the learners with an opportunity to obtain self-awareness of the way in which they learn. Moreover, such a training program guides the learners to seek ways of enhancing their learning experience. How strategy training influences reading comprehension has been the focus of few studies (Salataci \& Akyel, 2002; Mehrpour, Sadighi, \& Bagheri, 2012).Some of these studies have examined the instruction of writing strategies (e.g., Sasaki, 2000) while another strand of research has investigated teaching listening strategies (e.g. Thompson \& Rubin,1996; Bozorgian \& Pillay, 2013).

\subsection{Reading Strategies}

Some studies have identified the strategies used by students to improve their reading comprehension as a sub-field of different learning strategies (e.g. Brantmeier, 2002; Janzen, 1996; and Slataci \& Akyel, 2002). In the same vein, multiple definitions of reading strategies 
have been given by some theorists. For example, Barnett (1988) defines reading strategies as mental operations employed by readers when they seek to understand the text effectively.

In fact, reading strategies provide a window through which we can see the way in which readers perceive an activity or concept, what textual and non-textual clues they focus on, how they grasp what they have already read, and what type of reactions they make when they encounter a text whose interpretation is difficult. Reading strategies involve a wide-ranging repertoire of techniques (e.g. ranging from simply reading difficult parts twice or seeking to find the meaning of an unknown term from its context, to more complex strategies such as making a summary and connection between what is being read and one's background knowledge). Generally, as Carrell, (1989) says, scholars assert that when it comes to the use of strategy, there are differences between more and less proficient readers. Actually, readers can be divided with respect to whether or not they use reading comprehension strategies. One group consists of the passive, unskilled readers whereas the other one consists of active readers. Skilled readers both read and interact with the text.

Based on the results of multiple studies (e.g. Brown \& Palincsar, 1989; Carrell, Pharis, \& Liberto, 1989; Pearson \& Fielding, 1991), L2 instructors can set up programs to teach reading strategies to the learners. The resulting outcomes can give them a chance to enhance their performance on tests related to comprehension and recalling what is read. The findings of the investigations carried out on reading instruction and reading strategies (e.g., Davis, 2010; Khosravi, 2000; Salataci \& Akyel, 2002; Shokrpour \& Fotovatian (2009) show that providing reading comprehension strategy training had a positive effect on either students ' reading comprehension ability or their awareness of reading comprehension strategies.

A review of literature reveals a lot of studies conducted in the context of SLA with a focus on text-processing strategies (e.g., Dreyer \& Nel, 2003; Mokhatari \& Reichard, 2002, 2004; Pressley, 2000).Based on the research done on learners' metacognitive awareness of reading strategies, language learners make use of varying degrees of the following 3 reading strategies, i.e. global, support and problem solving (Nam \& Leavell, 2006; Madhumathi \& Ghosh, 2012). In their study, Madhumathi and Ghosh (2012) assessed the first year Indian ESL learners' awareness of reading strategy use. Moreover, they investigated how reading strategy use is related to the reading comprehension achievements of the ESL learners. The study used the following two instruments, e.g., SORS and RCT. The latter is an altered version of TOEFL reading comprehension.

Researchers have grouped reading strategies into the following three categories: the global, problem solving, and supporting. According to the results of the SORS, engineering students displayed the medium to high degrees of the application of reading strategies. The overall average application of reading strategies fell under medium level $(\mathrm{M}=3.39)$. The majority of learners went for problem solving strategies $(\mathrm{M}=3.78)$ while reading academic texts. As the second most appealing strategy, the participants used supporting strategy $(\mathrm{M}=3.27)$. The results showed that global strategy $(\mathrm{M}=3.24)$ was the least preferred strategy. The paired sample $t$-test results indicated statistically significant difference $(t=12.85)(p=0.00)$ in 3 categories of reading strategies and the total reading strategies. Except for global and 
supporting strategies, all other combinations of strategies were found to be statistically significant. Generally, there was a moderate correlation between reading strategy use and the learners' reading comprehension achievement.

\subsection{Reading Comprehension}

According to Gorjian, Pazhakh, and Prang (2012) reading comprehension is considered as one of the important skills through which a learner can maneuver his ability in an L2. Hosseni, Bakhshipour Khodaei, Sarfallah, and Dolatabadi (2012) carried out an investigation to examine the relationship between critical thinking ability, reading comprehension, and reading strategy use. To this end, 70 Iranian translation and literature students participated in the study. The instruments used to gather the data were as follows: 1- TOEFL, 2-reading comprehension test, 3-reading strategy inventory, and 4- a critical thinking ability test. The results showed a significant positive relationship between Iranian EFL readers' critical thinking ability and their use of reading strategy.

According to National Reading Panel (2000), prior to the 1980s there were very few comprehension instruction programs in the United States. Palinscar and Brown (1984) put forth the concept of reciprocal teaching which is a technique thereby learners are taught the abilities such as prediction, summarization, clarification, and asking questions while reading different sections of a text. This technique yielded positive outcomes. In the ensuing years till now, the educators and language teachers have considered the use of strategies like summarizing after each paragraph as effective strategies for improving learners' comprehension. The point is that learners can acquire better reading comprehension skills independently if the instructor provides them with explicit mental tools for unpacking text (Pressley, Michael, 2006). A wide range of reading strategies have been suggested by reading programs and educators.

Based on the results of a survey conducted by The National Reading Panel, only a subset of reading strategies(e.g. summarizing, asking questions, answering questions, comprehension monitoring, graphic organizers, and cooperative learning) were found to yield positive outcomes for readers. The Panel also reiterated that learners can benefit from the efficacy resulting from a combination of strategies as used in Reciprocal Teaching. Comprehension through discussion is concerned with lessons containing "instructional conversations". They create higher-level thinking chances for the learners. The discussions are aimed at promoting critical and aesthetic thinking about text. This, in turn, encourages the learners' full participation in classroom activities. As Vivian Thayer maintains, class discussions give the learners a chance to generate ideas and pose new questions.

An individual's ability to read various kinds of texts entails the application of diverse reading strategies and approaches. The learners would find many benefits in making their reading a dynamic and observable process. A proficient reader engages in interactions with the text, aiming to have a thorough grasping of the information beforehand. The following are some of the strategies used by good readers: prediction, making connection, making inference, making summary, analyzing and critiquing. Educators and instructors of reading can take advantage of many resources and activities to teach reading strategies in specific content areas and 
disciplines (e.g. graphic organizers, metacognitive strategies, double entry journals, interactive reading and note taking guides, predicting, and summarizing).

\subsection{Cooperative Learning}

Human beings are social by nature. Thus, we need to engage in social communication with others in various aspects of daily affairs. One way to achieve such a need i.e. socializing, is the formation of group working for educational goals. Most probably, there is no one who has not experienced engagement in a group work during his/her education. However, as Johnson \& Johnson (1992) maintain, it seems that traditional form of group work is not efficient enough to yield the desired outcomes such as higher-level thinking abilities and creative/critical thinking.

The reason is that traditional group work lacks the structure needed to enhance language learning. A majority of language teachers have experienced issues related to encouraging students to speak together in the L2. Put it other way, the learners fail to improve their communicative skills in the L2 in group work. Due to the lack of the mentioned structure in the group work in educational contexts, many efforts were made to make these activities more regular and effective by concentrating on instructional and pedagogical dimension of these activities. Árnadóttir (2014) maintains that during the last century, an effort was made to design an instructional framework with regards to cooperative learning. These cooperative theories have come to go abreast with discussions on how one can encourage learners to be more active in their studies and to assume more control of their own education in the best possible way.

Johnson et al., (1998) defines cooperative learning as an instructional method through which students engage in collaboration in small teams with the aim of achieving common learning objectives. He believes that cooperative learning is considered as an effective instructional strategy employed by the learners to reinforce their social development in a school setting. Through formation of small groups, students cooperate with each other to achieve individual and common goals. While participating in cooperative activities, students are after outcomes which can bring some benefits to them as well as to all other group members. Cooperative learning stands in sharp contrast to competitive learning (where learners work against each other to accomplish an academic goal that only one or a few learners can obtain) and individualistic learning.

A look at literature shows that this kind of learning leads to better outcomes regarding a large number of outcomes than traditional learning methods (Johnson \& Johnson, 1991; Slavin, 1995). Researchers have maintained that engagement in pair or group work improves practice opportunities to a great extent. This usually leads to reinforcement of oral skills, creating various activities in the classroom (McGroarty, 1993). Jia (2003) believes that effective language learning depends on participation in social interaction, leading to the satisfaction of communication needs in L2 as the learners in teams and subgroups can access more opportunities to talk and negotiate meaning than traditional methods.

In recent years, L2 education has concentrated on cooperative learning as an important concept and a classroom activity which is reflected in the establishment of subgroups and teams while 
learning. Cooperative Learning gives the learners a chance to put the language to use. Moreover, as Kagan, (2014) says, it also enables them to discover the vocabulary and the grammar for themselves and they can learn how to make manipulations in the language in order to satisfy their needs.

Many studies (e.g., Law, 2011; Liao \& Oescher, 2009; Suh, 2009) have showed the usefulness of the application of cooperative learning on reading comprehension. Some studies have showed that the application of cooperative techniques provides the learners with more opportunities to engage in interaction with each other, resulting in better gains with regards to reading and decreasing the level of anxiety (Gillies \& Ashman, 2000). On the other hand, a group of research has shown that the use of cooperative techniques in reading comprehension does not yield any better outcomes compared to traditional approaches (Gladwin, \& Stepp-Greany, 2008; Zoghi, Mustapha, Maasum, 2010).

Sittilert (1994) examined the impact of Cooperative Integrated Reading and Composition (CIRC) on reading comprehension as well as the students' attitudes towards the application of these techniques. The subject were 106 learners taking part in an English Reading class. They were categorized into two groups. The researcher made use of CIRC method to instruct the experimental group and for the control group he used the traditional approach building on the instructor's manual. The findings of the posttest of reading showed that the learners in the experimental group were better in terms of reading comprehension and overall their perception of the techniques were also positive.

Meteetum (2001) conducted a case study to investigate the effect of the use of jigsaw technique with nine second-year English major students. He ran a qualitative design and the data were collected using the following four instruments: grammar test, a structured field observation, a semi-structured interview and a reflective journal. The findings indicated that all the students had higher academic as well as achievement scores after using jigsaw techniques.

\section{Research Questions}

In line with the objectives of the present study, the following research questions were formulated:

RQ1: Do CL techniques have any significant effect on intermediate Iranian EFL learners' reading comprehension?

RQ2: Do CL techniques have any significant effect on intermediate Iranian EFL learners' reading strategies?

\section{Methodology}

\subsection{Participants}

In this study 90 EFL learners from Aran Language Institute in Khouzestan, Ahwaz took the Preliminary English Tests (PET) so, that a group of them who turn out to be homogeneous could be extracted from them. Based upon their scores on this test, 60 learners whose scores were one standard deviation above and below the mean were selected, and divided into two 
groups, Control group, and Experimental group. Their age ranged from 20-30.The PET test which was used to homogenize the participants was pre-piloted on 30 learners with the same characteristics of age, gender, and proficiency level as the target group. The writing section of the PET test was scored by two raters, the researcher as a teacher, and her colleague who had an M.A in EFL with 10 years of teaching experience. The whole term consisted of 18 sessions, and 12 sessions were assigned for the treatment, spanning over two months.

\subsection{Instruments}

The following instruments were utilized in this study to accomplish the purpose of the investigation.

\subsubsection{A Preliminary English Test (PET)}

A Preliminary English Test (PET) was administered for determining the proficiency level of the participants prior to the start of the treatment. The test was piloted on a sample group including 30 learners with the same characteristics as the target sample. This test covers the four main skills: reading, writing, listening, and speaking. In this study two sections of this test were used to homogenize the participants. Reading section has 5 parts and 35 reading comprehension questions. At first part there are5 questions, learners have to look at very short texts, such as signs and messages, postcards, notes, emails, labels, etc, and then select one of the correct Three-option multiple choice items (A-C) on their answer sheet. At the second part learners must match five descriptions of people to eight short texts, and mark the correct letter $(\mathrm{A}-\mathrm{H})$. At the third part also there are ten items with an adopted-authentic long text, and learners should choose one of the true or false answer on their answer sheet (11- 20). The fourth part consisted of a long text for reading comprehension, and four option multiple-choice items (21-25). The last part has a factual or narrative text for checking the understanding of vocabulary, and grammar in a short text, with 10 Four-option multiple choice cloze (26- 35). Writing section consisted of 3 parts and 8 questions. In the first part there are some sentences and for each question, the participants should complete the second sentences so that it means the same as the first. In the second part there is a topic and the EFL learners should write 35-45 words on their answer sheet about it. In the last part there are two questions and the EFL learners should write an answer in about 100 words to one of the questions on their answer sheet. The participants were expected to answer the questions in 1 hour and 30 minutes (45 minutes for reading section and 45 minutes for writing section). Item facility, item discrimination were calculated and reliability of this test was found as high as 0.94 . As a result of item analyses, no item was discarded.

In order to rate all the writings in this study the researcher used the General Mark Schemes for writing by Cambridge. Writings were rated on five aspects of writing: content, organization vocabulary, and language use. The rating was done on the basis of criteria stated in the rating scale, and possible range of score was $0-5$ and later inter- rater reliability of the two raters' scores was calculated. 90 EFL learners took this test, and 60 learners who scored within one standard deviation above, and below the mean were selected, and divided into 2 groups, and 4 classes. This test was applied to achieve two goals: 1: to demonstrate the level of the participants, and homogenization, and 2: to check the reading comprehension of those 60 
homogenized EFL learners before treatment. So, for this reason, their scores were also applied as pre- treatment test.

\subsubsection{A Metacognitive Awareness of Reading Strategies Inventory (MARSI) Questionnaire}

As mentioned previously this study was conducted to investigate the effect of CL techniques on intermediate Iranian EFL learners' reading comprehension and reading strategies. So, as one dependent variable in this study was reading strategies of the learners, this instrument was used to homogenize the learners of the two groups in terms of their reading strategies before starting the treatment. The Metacognitive Awareness of Reading Strategies Inventory (MARSI) Questionnaire (version 1.0) was developed by Kouider Mokhatari and Carla Reichards, (2002). It is designed to assess adolescent, and adult readers' metacognitive awareness, and perceived use of reading strategies while reading academic, or school-related materials (Mokhtari \& Reichards, 2002). The questionnaire was revised by the authors in 2002 . The reliability of the test was 0.89 . It consisted of 30 statements using a 5-point Likert-type scale ranging from 1 (I never do this) to 5 (I always do this). According to Mokhtari, and Reichard (2002) it is important at this point to remind students that their responses only refer to the strategies they use when reading school-related materials. They should also be encouraged to respond honestly to each statement in the inventory, and to ask questions about any aspect of the inventory they do not understand. The learners should circle the correct number after reading each statement. There were not any right or wrong answer to this statements. The questionnaire also included 3 strategies subscales:

Global Reading Strategies (items: 1, 3, 4, 7, 10, 14, 17, 19, 22, 23, 25, 26, and 29), ProblemSolving Strategies (items: 8, 11, 13, 16, 18, 21, 27, and 30), and Support Reading Strategies (items: 2, 5, 6, 9, 12, 15, 20, 24, 28). According to Mokhtari, and Reichard (2002), for scoring the researcher transferred all the scores obtained by learners to its subscale, and added them up in each column to obtain a total score, then divided by the number of items (30) to get an average response for the entire inventory as well as for each strategy subscale. Interpretation of an overall average is as follows: 3.5 or higher equals high, 2.5 - 3.4 equals Medium, and 2.4 or lower equals Low. According to inventory the overall average shows how often one uses the strategies, and the average of each subscale shows which subscale strategies one uses more in their reading. According to Mokhtari, and Reichard (2002) adopted from Oxford (1990, p. 297300 ) the strategies used depend on the user's reading abilities, in another word, better reading ability will result in better strategy use.

\subsubsection{Reading Comprehension Test}

PET reading test was used both as the pre-treatment and posttest in this study. The test was piloted on 30 participants with the same characteristics of the main participants of the study. Another reading comprehension test drawn from another version of PET was used as the posttest. This test covers the four main skills: reading, writing, listening, and speaking. Reading section which was used as posttest in this study had 5 parts and 35 reading comprehension questions. There are some sentences and for each question, the participants should complete the second sentences so that it means the same as the first. The participants were expected to answer the questions in this part in 45 minutes. Reliability of this test was 
calculated as high as 0.94 . So, for this reason no items were discarded as a result of item analyses.

\subsubsection{A Course Book}

In order to fulfill this study the researcher applied another instrument during the 12 sessions of treatment to work on learners' reading comprehension. So, for this reason she selected the "ACTIVE 2 skills for reading book", by Neil. J Anderson (2013), the third edition, for teaching reading comprehension. This book consisted of a wide variety of texts for reading comprehension including articles, journals, blogs, and interviews in 24 chapters, and 12 units, each one consisted of: before reading activities, reading texts, reading comprehension (check your understanding), critical thinking, vocabulary comprehension, vocabulary skills, and real life skills activities. In this study six different units were selected, and were taught to the learners during 12 sessions. It is worth mentioning that the experimental received instructions by cooperative learning techniques while the control group were taught traditionally.

\subsection{Procedure}

In order to fulfill the present study the following procedure was followed to accomplish it: Prior to the start of the main study, the researcher piloted the PET on 30 learners with the similar characteristics to the target sample. Two parts of the PET test were administered: the reading and writing sections. The scores of the PET test were calculated out of 42 because the test had 42 items and each item was given one point. The students answered the questions in 1 hour and 30 minutes. The reliability and item analyses of the PET test were estimated. At the next step, the piloted PET was administered to 90 EFL learners, and based on their mean score, 60 learners who scored one standard deviation above, and below the mean were selected and divided randomly into 2 groups, Experimental, and Control groups. The learners' PET reading and writing scores were considered also as their reading, and writing pre-treatment test scores. The writing section of the PET test was scored by two raters, the researcher as a teacher, and her colleague. In order to rate all the writings in this study the researcher used the General Mark Schemes for writing by Cambridge. The researcher made sure that there was no significant difference between the two groups' PET reading, scores at the outset.

Then the two groups were given a metacognitive reading strategies inventory questionnaire to check the learners' reading strategies usage, and that there was no significant difference between the two groups in this regard before the intervention. The learners were briefed about the instructions of how to fill out the questionnaires, and were asked to complete them in due time, 10-12minutes, (Mokhtari \& Reichard, 2002), bearing in mind that there were no right or wrong answers. It is worth mentioning that in order to encourage the participants to answer with more care and honesty, they were assured that their responses to the instruments were planned to be used only for gathering information for the research. It should be also noted that the researcher was present while participants were responding to questionnaires to provide further explanations if required.

The whole semester lasted for 18 sessions, and12 sessions were dedicated to the treatment. Since the researcher could not put the participants in two classes of thirty she divided them into 
four classes of fifteen. Therefore, there were two classes in each group. Then, each 2 sessions, one unit from the course book, Active 2, was selected for both groups, and the reading parts were worked on as the treatment. The experimental group was instructed through "Number heads together", and "Showdown", two types of the CL techniques, and the control group was instructed via traditional instructional technique.

At the first session the teacher who was the researcher informed the experimental group about the CL techniques which they were going to be used during the treatment. The first six sessions were allocated for teaching reading through "Number heads together", and the six remaining sessions were assigned for "Showdown" techniques. Based on Number heads together technique, the teacher grouped the class into four different groups including three groups of four learners, and one group with three learners, and numbered learners from 1 to 4 . It is worth mentioning here that the researcher changed the group members each two sessions in order to make more positive interaction among the learners. After grouping, the students read a course book question, or the teacher posed an inferential question from the course book text, and students put their heads together to discuss the answer. Then the teacher randomly called a number, and students in each group with that number explained their group's response.

After six sessions of teaching reading comprehension through Number heads together, the teacher informed the experimental group that they were going to work with another different kind of cooperative techniques which is called "Showdown", and divided the class as before into groups of 1 to 4, but this time assigned a "leader" for each group. Then the teacher read a question from the course book, and learners wrote their answers individually on their notebook, or their books, and when all the members were ready the leader said: "Showdown", and team members discussed and compared their answers with each other, and finally the leader explained their final answer. In contrast with the experimental group, the control group during 12 sessions were instructed traditionally via teacher-based instruction through which the teacher, or one of the learners read a text, and teacher posed a question from the text, or the activities, and called one of the students to answer to the question without any discussion, and consulting with their other peers. About 45 to 50 minutes of each session were allocated to reading including grouping (for experimental groups), before reading activities, reading a text, after reading activities, and asking, and answering questions (for both groups). It should be noted here that during this treatment the teacher,(the researcher), did not teach reading strategies separately to the learners, and just measured the effect of cooperative learning techniques on intermediate EFL learners' reading strategies after treatment. At the end of the course all the participants underwent another PET reading comprehension as post-treatment test in order to investigate the result of the treatment. They also took the metacognitive reading strategies inventory questionnaire (MARSI, 2002) again as the posttest.

\section{Results}

\subsection{Piloting PET}

The first stage was to pilot the PET test in order to homogenize the students based on their general proficiency. The reliability of the PET test was estimated as reported below. 
Table 1. Descriptive Statistics of PET Piloting

\begin{tabular}{rccccccc}
\hline & N & Range & Minimum & Maximum & Mean & Std. Deviation & Variance \\
\hline PET piloting & 30 & 29 & 7 & 36 & 21.4 & 11.57 & 134.00 \\
\hline Valid N (listwise) & 30 & & & & & & \\
\hline
\end{tabular}

Table 2

Reliability Statistics

\begin{tabular}{|c|c|c|c|c|}
\hline & \multicolumn{4}{|c|}{ Cronbach's Alpha Based on } \\
\hline & Cronbach's Alpha & & & $\mathrm{N}$ of Items \\
\hline .944 & & .944 & 42 & \\
\hline
\end{tabular}

As it is shown in table 2 the reliability of the PET test was estimated 0.94. All items went through item analyses, and no item was discarded. Inter-rater reliability of the scores given by the two raters to the writings of the learners of both groups was estimated. The following tables show the result:

Table 3. Correlation between the Raters' Scores to the CG Pre-Treatment Writings

\begin{tabular}{llrrr}
\hline & & CGpreR1 & \multicolumn{1}{c}{ CGpreR2 } \\
\hline \multirow{2}{*}{ CGpreR1 } & Pearson Correlation & 1 & $.966^{* *}$ \\
\cline { 2 - 5 } & Sig. (2-tailed) & 30 & .000 \\
\cline { 2 - 5 } & $\mathrm{N}$ & $.966^{* *}$ & 30 \\
\hline \multirow{3}{*}{ CGpreR2 } & Pearson Correlation & .000 & 1 \\
\cline { 2 - 5 } & Sig. (2-tailed) & 30 & 30 \\
\cline { 2 - 5 } & $\mathrm{N}$ & & \\
\hline
\end{tabular}

**. Correlation is significant at the 0.01 level (2-tailed).

As shown in the above table, the correlation between the two raters' scores given to the pre-treatment writings of the control group turned out to be significant $(r=.96, p=.000<.05)$.

Table 4. Correlation between the Raters' Scores to the EG Pre-Treatment Writings

\begin{tabular}{llrrr}
\hline & & EGpreR1 & \multicolumn{1}{c}{ EGpreR2 } \\
\hline \multirow{3}{*}{ EGpreR1 } & Pearson Correlation & 1 & $.954^{* *}$ \\
\cline { 2 - 4 } & Sig. (2-tailed) & 30 & .000 \\
\cline { 2 - 4 } & $\mathrm{N}$ & $.954^{* *}$ & 30 \\
\hline \multirow{3}{*}{ EGpreR2 } & Pearson Correlation & .000 & 1 \\
\cline { 2 - 4 } & Sig. (2-tailed) & 30 & 30 \\
\cline { 2 - 4 } & $\mathrm{N}$ & & \\
\hline
\end{tabular}

**. Correlation is significant at the 0.01 level (2-tailed). 
The above table depicts that the correlation between the two raters' scores given to the pre-treatment writings of the experimental group turned out to be significant $(\mathrm{r}=.95$, $\mathrm{p}=.000<.05)$.

\subsection{Estimating the Reading Strategies Pre-treatment Scores}

Before the start of the treatment, the researcher made sure that the learners of the two groups were homogeneous regarding the dependent variables. The following table shows the descriptive statistics of the reading strategies pre-treatment scores of the two groups including the skewness data:

Table 5. Descriptive Statistics of the RS pretest scores

\begin{tabular}{lcccccc}
\hline & & & & & & \multicolumn{2}{c}{ Skewness } \\
& \multicolumn{2}{c}{$\mathrm{N}$} & Mean & Std. Deviation & Skewness & ratios \\
\cline { 2 - 8 } & Statistic & Statistic & Statistic & Statistic & Std. Error & \\
\hline contRsqPre & 30 & 2.6673 & .42980 & -.130 & .427 & -.30 \\
\hline expRsqPre & 30 & 2.5510 & .34053 & -.505 & .427 & 1.18 \\
\hline Valid N (listwise) & 30 & & & & & \\
\hline
\end{tabular}

As the above table shows, both sets of scores were normally distributed as the skewness ratios were less than 1.96. The mean scores of the two groups turned out to be very close to each other. The following table shows the result of the $t$ test on the means:

Table 6. Independent Samples Test on the RS pretest

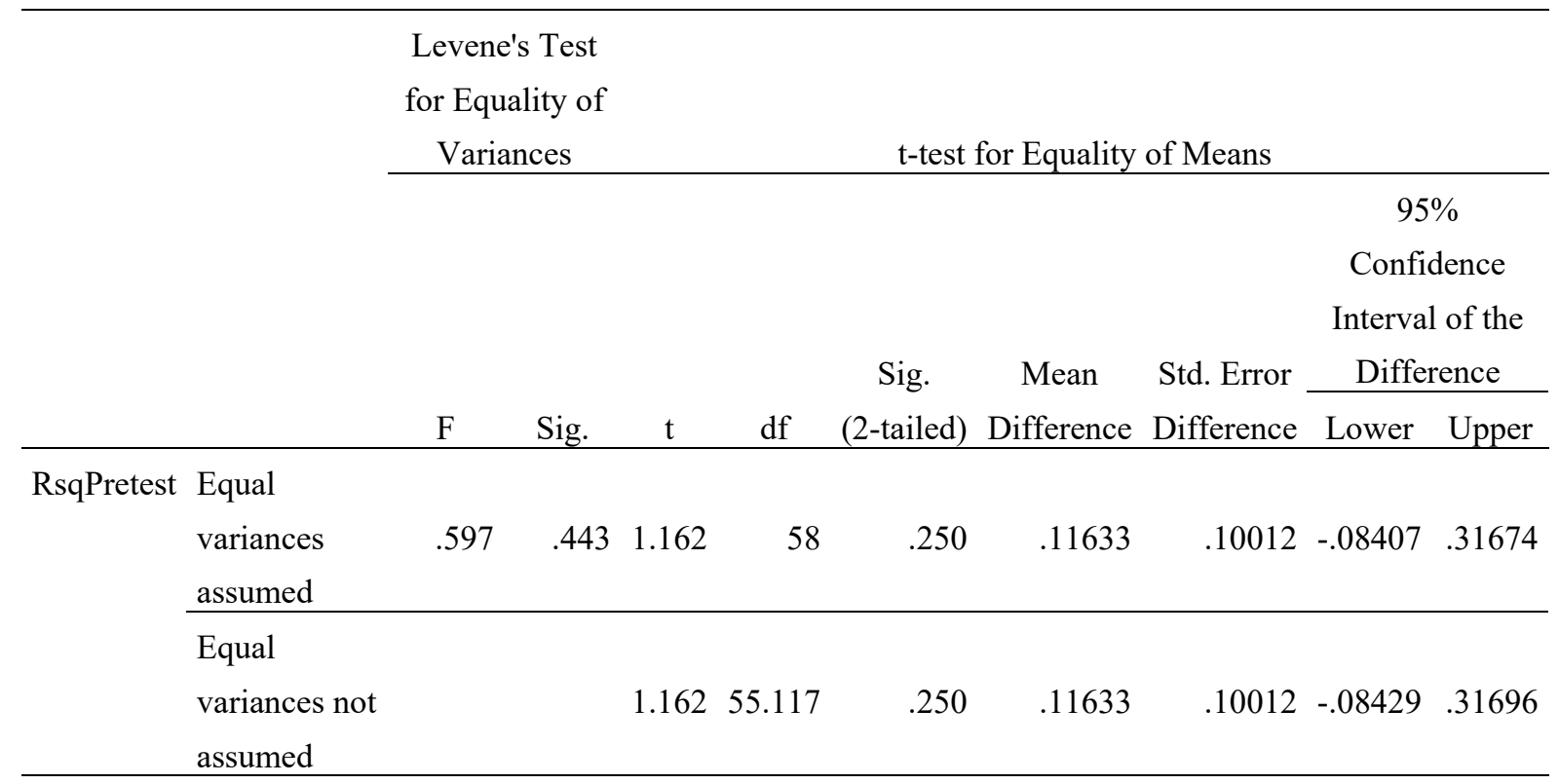

As the above table depicts, the variances were homogeneous $(\mathrm{F}=.597, \mathrm{p}=.443>.05)$, and there was no significant difference between the means of the two groups $(t=1.16, p=.25>.05)$. Thus, it was concluded that there was no significant difference between the reading strategies of the two groups (experimental and control) before the intervention. 


\subsection{Estimating the Reading Comprehension Pretest Scores}

Also, the homogeneity of the two groups regarding their reading comprehension had to be checked before the outset of the treatment. The following table shows the relevant descriptive statistics:

Table 7. Descriptive Statistics on the Reading Comprehension Pretest

\begin{tabular}{lcccccr}
\hline & & & & & \multicolumn{2}{c}{$\begin{array}{c}\text { Skewness } \\
\text { ratios }\end{array}$} \\
\hline & Statistic & Statistic & Statistic & Statistic & Std. Error & \\
\hline contReadPre & 30 & 21.7000 & 3.55402 & .097 & .427 & .22 \\
\hline expReadPre & 30 & 22.8000 & 3.28424 & -.129 & .427 & -.30 \\
\hline Valid N (listwise) & 30 & & & & & \\
\hline
\end{tabular}

Shown in the above table, the skewness ratios of both sets of scores fell within the normality range of \pm 1.96 , hence their normal distributions. The following table displays the result of the $t$ test:

Table 8. Independent Samples Test on the Reading Comprehension Pretest

\begin{tabular}{|c|c|c|c|c|c|c|c|c|c|}
\hline & & $\begin{array}{r}\text { Leve } \\
\text { Test } \\
\text { Equali } \\
\text { Varial }\end{array}$ & $\begin{array}{l}\text { fone's } \\
\text { ity of } \\
\text { inces }\end{array}$ & & & t-test $\mathrm{f}$ & for Equality & of Means & \\
\hline & & & & & & Sig. & Mean & Std. Error & $\begin{array}{c}95 \% \text { Confidence } \\
\text { Interval of the } \\
\text { Difference } \\
\end{array}$ \\
\hline & & $\mathrm{F}$ & Sig. & $\mathrm{t}$ & $\mathrm{df}$ & (2-tailed) & Difference & Difference & Lower Upper \\
\hline ReadingPretest & $\begin{array}{l}\text { Equal } \\
\text { variances } \\
\text { assumed } \\
\end{array}$ & .935 & .338 & -1.245 & 58 & .218 & -1.10000 & .88350 & -2.86852 .66852 \\
\hline & $\begin{array}{l}\text { Equal } \\
\text { variances } \\
\text { not } \\
\text { assumed } \\
\end{array}$ & & & -1.245 & 57.642 & .218 & -1.10000 & .88350 & -2.86875 .66875 \\
\hline
\end{tabular}

As the above table demonstrates, the variances homogeneity was assumed, $(\mathrm{F}=.935$, $\mathrm{p}=.338>.05$ ), and the difference between the two mean scores turned out to be non- significant $(\mathrm{t}=1.24, \mathrm{p}=.218>.05)$. Therefore, the researcher felt assured that the two groups were homogeneous regarding their reading comprehension proficiency, and as such, any possible final difference could be logically attributed to the treatment. 


\section{Macrothink}

\subsection{Testing the Null Hypotheses}

To test the hypotheses, the researcher opted for a MANOVA, as there were two dependent variables that could be considered as dealing with relevant constructs. But, firstly, the assumptions of normality, outliers, and homogeneity of regression were checked:

Table 9. Descriptive Statistics of the Posttest Scores

\begin{tabular}{|c|c|c|c|c|c|c|}
\hline & $\mathrm{N}$ & Mean & Std. Deviation & \multicolumn{2}{|c|}{ Skewness } & $\begin{array}{c}\text { Skewness } \\
\text { ratios }\end{array}$ \\
\hline & Statistic & Statistic & Statistic & Statistic & Std. Error & \\
\hline contRsqPost & 30 & 2.6587 & .40165 & -.286 & .427 & .66 \\
\hline expRsqPost & 30 & 3.8467 & .79383 & -4.110 & .427 & -9.62 \\
\hline contReadPost & 30 & 22.1000 & 3.22009 & .269 & .427 & .62 \\
\hline expReadPost & 30 & 35.7333 & 4.69727 & .582 & .427 & 1.36 \\
\hline Valid N (listwise) & 30 & & & & & \\
\hline
\end{tabular}

As the above table shows, the skewness ratio of the experimental group's reading strategies posttest scores turned out to be skewed, as the related ratio (9.62) exceeds 1.96. The existence of possible outliers was checked through the following graph.

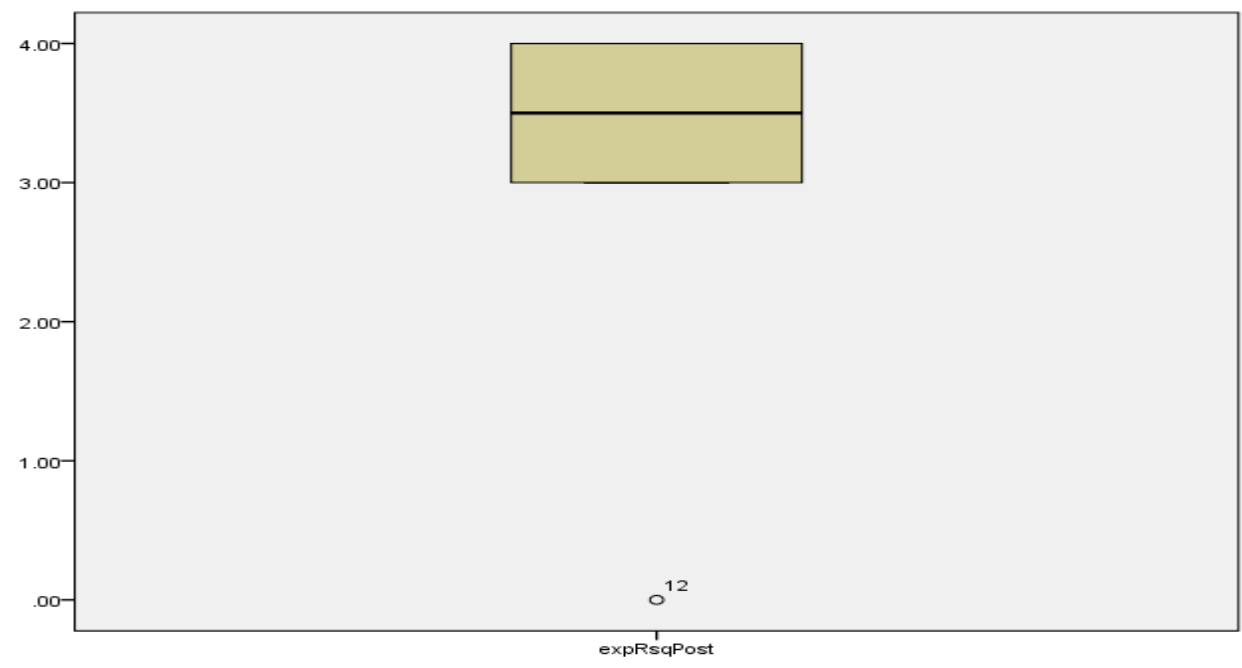

Figure 1. Box plot representing the distribution of the scores

As the above figure demonstrates, the circle standing at the bottom signals the existence of an influencing outlier. Also, the following table shows if multivariate outlier exists as well. 
Table 10. Residuals Statisticsa

\begin{tabular}{lrrrrr}
\hline & Minimum & \multicolumn{1}{c}{ Maximum } & \multicolumn{1}{c}{ Mean } & \multicolumn{1}{c}{ Std. Deviation } & N \\
\hline Predicted Value & .8363 & 2.3427 & 1.5000 & .44235 & 60 \\
\hline Std. Predicted Value & \multicolumn{1}{c}{1.500} & 1.905 & .000 & 1.000 & 60 \\
\hline $\begin{array}{l}\text { Standard Error of Predicted } \\
\text { Value }\end{array}$ & .033 & .174 & .051 & .020 & 60 \\
\hline Adjusted Predicted Value & .4311 & 2.3903 & 1.4886 & .46532 & 60 \\
\hline Residual & -.39299 & .78382 & .00000 & .24201 & 60 \\
\hline Std. Residual & -1.596 & 3.183 & .000 & .983 & 60 \\
\hline Stud. Residual & -1.618 & 4.504 & .019 & 1.081 & 60 \\
\hline Deleted Residual & -.40377 & 1.56886 & .01141 & .30600 & 60 \\
\hline Stud. Deleted Residual & -1.642 & 5.562 & .037 & 1.167 & 60 \\
\hline Mahal. Distance & .088 & 28.540 & 1.967 & 3.718 & 60 \\
\hline Cook's Distance & .000 & 6.772 & .124 & .873 & 60 \\
\hline Centered Leverage Value & .001 & .484 & .033 & .063 & 60 \\
\hline
\end{tabular}

a. Dependent Variable: grouping

As shown above, the maximum value of Maha Distance exceeds 13.82 which is the critical value when there are two dependent variables. Therefore, an influencing outlier exists also. Homogeneity of regression, as another condition for MANOVA, was also checked through the following table.

Table 11. Box's Test of Equality of Covariance Matricesa

\begin{tabular}{lr}
\hline Box's M & 16.608 \\
\hline F & 5.329 \\
\hline df1 & 3 \\
\hline df2 & 605520.000 \\
\hline Sig. & .001 \\
\hline
\end{tabular}

As the above table shows, the sig value is less than .05, which implies that the assumption is violated. With the violation of the above assumptions, the researcher decided to test the hypotheses through two $t$ tests. The following table shows the $t$ test output for the reading comprehension posttest scores.

Table 12. Group Statistics of the Reading Comprehension Posttest Scores

\begin{tabular}{|c|c|c|c|c|c|}
\hline & Grouping & $\mathrm{N}$ & Mean & Std. Deviation & Std. Error Mean \\
\hline \multirow[t]{2}{*}{ ReadingPost } & Control & 30 & 22.1000 & 3.22009 & .58790 \\
\hline & experimental & 30 & 35.7333 & 4.69727 & .85760 \\
\hline
\end{tabular}

The above table depicts that the experimental group outperformed the control group by virtue of the mean scores they obtained (35.73 vs. 22.10). The following table shows if the difference was significant. 
Table 13. Independent Samples Test on the reading Comprehension Posttest Scores

\begin{tabular}{|c|c|c|c|c|c|c|c|c|c|c|}
\hline & & $\begin{array}{r}\text { Leve } \\
\text { Test } \\
\text { Equal } \\
\text { Varia }\end{array}$ & $\begin{array}{l}\text { ne's } \\
\text { for } \\
\text { ty of } \\
\text { nces }\end{array}$ & & & t-tes & t for Equalit & $y$ of Means & & \\
\hline & & & & & & Sig. & Mean & Std. Error & $\begin{array}{r}95 \% \text { Co } \\
\text { Interva } \\
\text { Diffe } \\
\end{array}$ & $\begin{array}{l}\text { idence } \\
\text { of the } \\
\text { nce }\end{array}$ \\
\hline & & $\mathrm{F}$ & Sig. & $\mathrm{T}$ & Df & (2-tailed) & Difference & Difference & Lower & Upper \\
\hline RedingPost & $\begin{array}{l}\text { Equal } \\
\text { variances } \\
\text { assumed }\end{array}$ & 3.12 & .08 & -13.11 & 58 & .000 & -13.6 & 1.03 & -15.7 & -11.55 \\
\hline & $\begin{array}{l}\text { Equal } \\
\text { variances } \\
\text { not } \\
\text { assumed }\end{array}$ & & & -13.11 & 51.3 & .000 & -13.6 & 1.03 & -15.7 & -11.54 \\
\hline
\end{tabular}

The above table exhibits that the equality of variances was assumed $(F=3.12, p=.08>.05)$, thus the first row was used for the result of $t$ test. As it is shown there, the difference between the mean scores of the two groups turned out to be significant $(t=13.11, \mathrm{p}=.000<.05)$. Therefore, the null hypothesis is rejected implying that cooperative learning significantly improved the learners' reading comprehension.

To test the second null hypothesis, Mann-Whitney U test was utilized as the RS posttest scores of the experimental group was shown to be skewed.

Table 14. Mann-Whitney U test on the RS Posttest

Hypothesis Test Summary

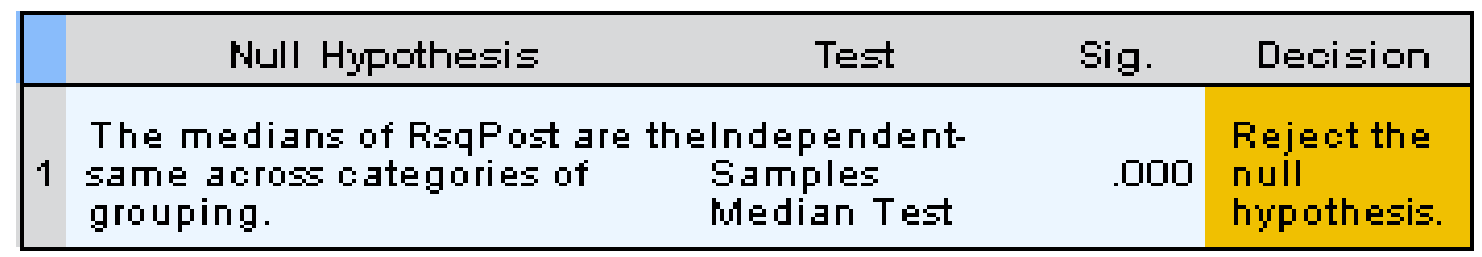

Asymptotic significances are displayed. The significanoe level is 05 .

As displayed in the above table, the difference between the two groups' posttest mean scores on the reading strategy questionnaire turned out to be significant $(\mathrm{p}=.000<.05)$. Thus, the null hypothesis is rejected, and by virtue of the obtained means by the two groups (2.65 vs 3.84), and the fact that the two groups were the same regarding this trait before the treatment, it is 
concluded that cooperative learning could significantly improve reading strategies of the learners. The following bar graphs represent the posttest mean scores of the two groups.

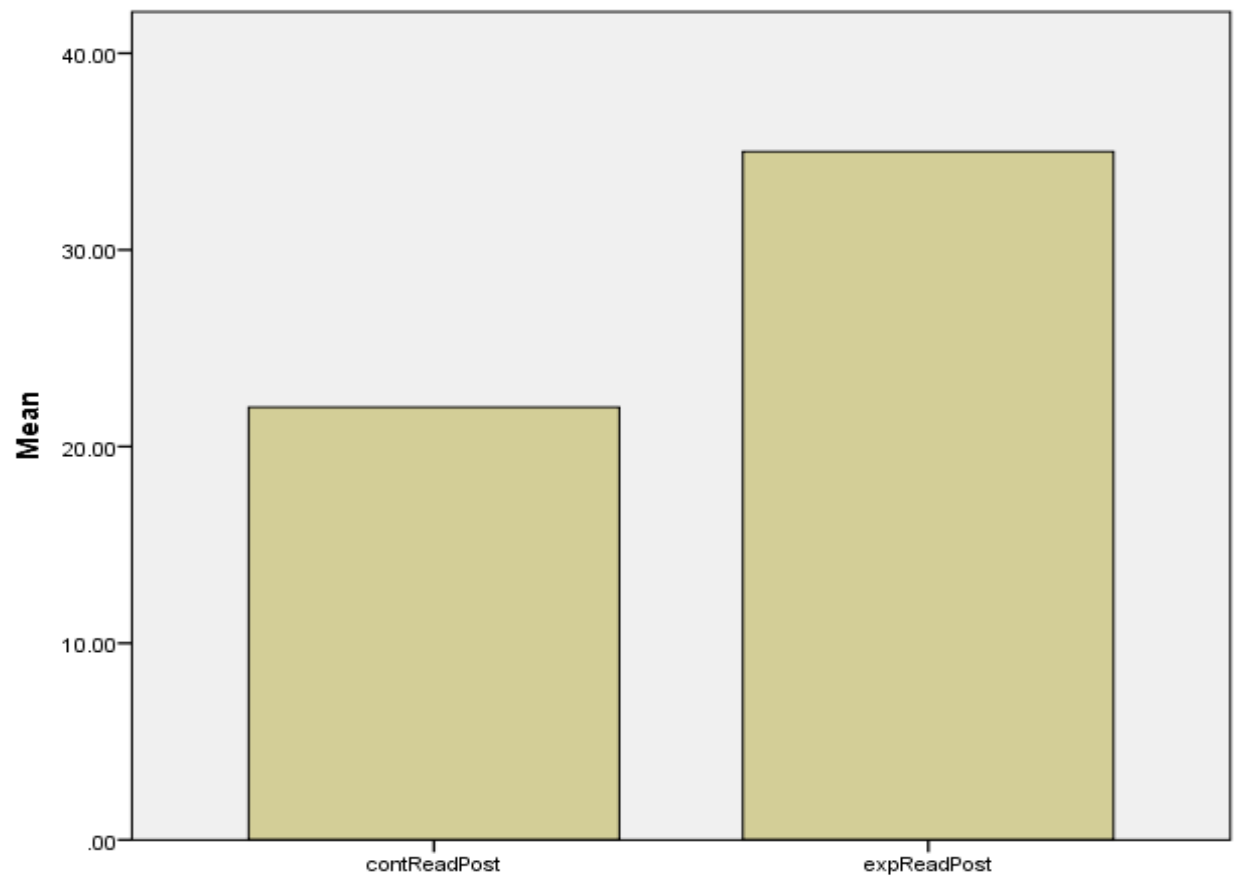

Figure 2. Bar graph representing the reading comprehension posttest scores of the two groups The following graph shows the two groups' mean scores on the reading strategies posttest:

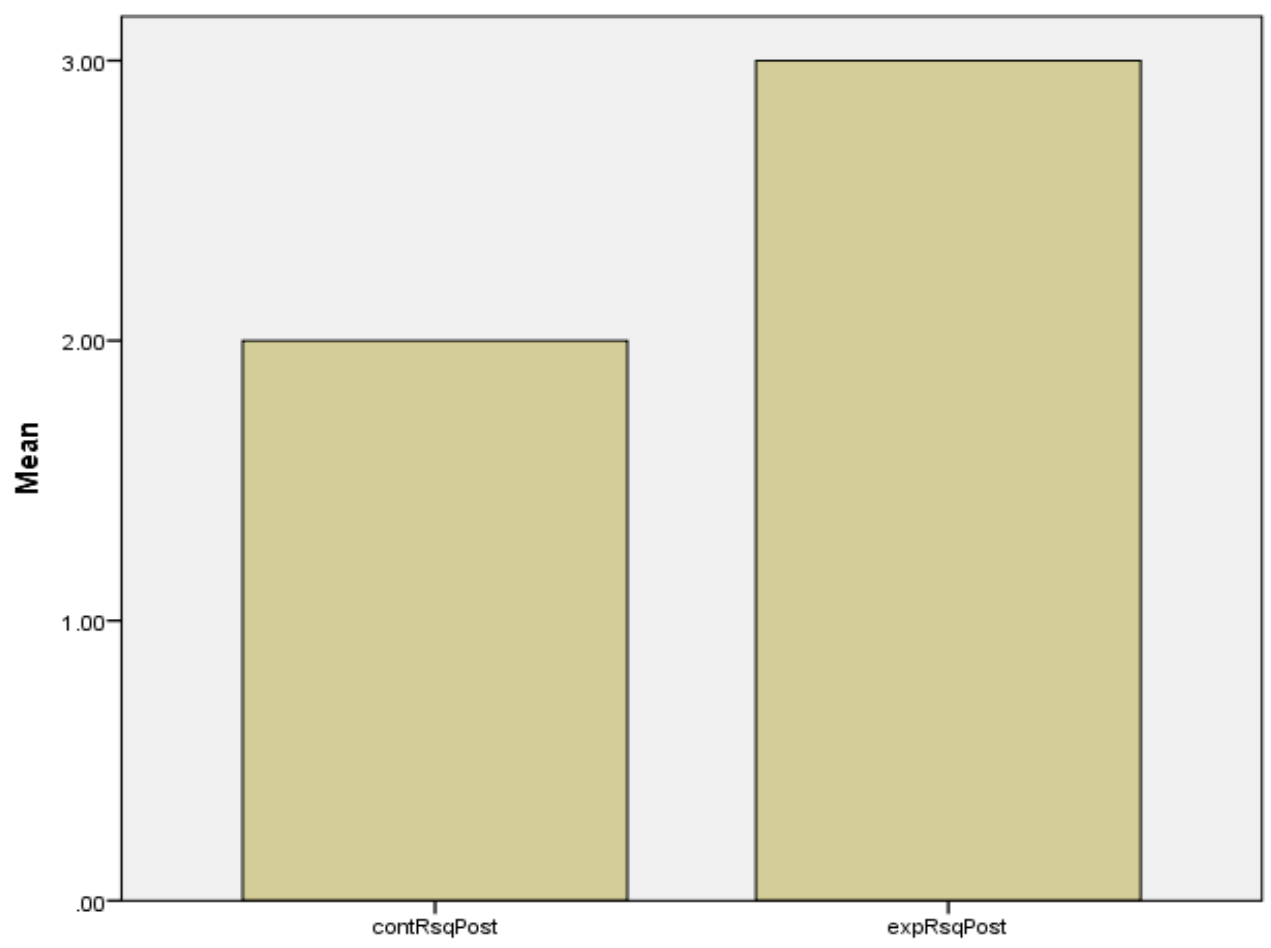

Figure 3. Bar graph representing the reading strategies posttest scores of the two groups 


\section{Discussion}

In this study the effect of cooperative learning techniques on intermediate Iranian EFL learners' reading comprehension, and reading strategies was shown to be significantly positive. Regarding the related literature the results, and finding of the study are discussed in this part. Given the fact the participants of both groups did not have any familiarity with the selected reading course book, and they were homogenous regarding their reading comprehension proficiency at the outset, but at the end of the treatment the experimental who received cooperative learning techniques outperformed the control group on the two dependent variables of this study, reading comprehension, and reading strategies, it can be concluded that cooperative learning techniques improved the intermediate Iranian EFL learners' reading comprehension, and reading strategies.

It is likely that cooperative learning techniques encourage learners to help each other in order to achieve their common goals, while in non-cooperative classes learners are working competitively, or individually in order to achieve grades as their academic goals (Richards \& Rodgers, 2000, p.195 cited from Johnson, 1994, p.4). In cooperative classes students work in groups because they know that their success or failure depends on their peers' success or failure, sink or swim together, (Johnson \& Rodgers, 1994, p.1). In cooperative classes learners have an opportunity to interact, and communicate with each other (Jacobs, Crookall \& Thiyaragarajali, 1997; Harmer, 2011; Jacobs, 1997). Most of the studies on cooperative learning has shown the effectiveness of these kind of techniques which promotes higher achievements, more interpersonal relationship, and higher self-esteem than traditional, individualistic, and competitive efforts (Gomleksize, 2007; Johnson \& Johnson, 1994, Mirzaei, 2012). Cooperative learning can also improve learners' critical thinking (Bayraktar, 2011, p.63 cited by Kazemi, 2012, p.172). Kagan (1992) noted that some authors suppose critical thinking at the same level of focus as the basic language skills of reading, writing, listening, and speaking (Dabaghmanesh, Zamanian \& Bagheri, 2013).

Rahvard (2010) found out that cooperative learning techniques have an effect on reading comprehension, and can be used as an instructional techniques for teaching reading comprehension (p.9). According to the findings of this study it has been proved that cooperative learning techniques had a significant effect on reading comprehension in the cases where intermediate Iranian EFL learners' have difficulties in their reading process. It also showed cooperative learning techniques can improve learners' reading strategies even if reading strategies were not taught to the learners directly, and specifically.

\section{Conclusion}

The results of the present study showed the significant effect of cooperative techniques on intermediate Iranian EFL learners' reading comprehension, and reading strategies. Looking back at the literature one can notice how many studies, and researches have been done on the effectiveness of cooperative learning techniques in the process of language learning skills, especially the reading comprehension. For example in the study on the effect of cooperative learning techniques on reading comprehension skills in Turkish as a foreign language by, Bolkubas, Keskin, and Polat (2011), they came to the conclusion that cooperative learning 
techniques have more effect on improving Turkish EFL learners' reading comprehension rather than traditional teaching methods. Also on studies that have done by Javadi Rahvard (2010), and Mirzaei (2012) they found that cooperative learning techniques can be used as an instructional strategy for improving reading comprehension. Findings related to the present study may have some implications for the English teachers, learners and material developers that may help them in EFL language learning, teaching, and testing in order to shift the focus from teacher-centered activities to learner-centered ones.

\section{References}

Abdullah, M., \& Jacobs, G. (2004). Promoting cooperative learning at primary school. TESL-EJ, 7(4), 52-69.

Anderson, S. (2013). Lawrence in Arabia: War, Deceit, Imperial Folly and the making of the modern middle east. New York, NY: Double day.

Árnadóttir, K. H. (2014). Cooperative learning in foreign language teaching: A Study of the Use of Group Work in Language Studies in Icelandic Secondary Schools. Unpublished MA Thesis. HáskóliÍslands. Hugvísindasvið University.

Barnett, M. A. (1988). Reading through context: How real and perceived strategy affects L2 comprehension. The Modern Language Journal, 72(2), 150-162. http://dx.doi.org/10.1111/j.1540-4781.1988.tb04177.x

Bloom, B., S. (1971). "Mastery Learning", in Block,J H (ed), Mastery Learning, theory and Practice, (pp. 258-269). New York: Holt, Rinehart and Wilson.

Bloomfield, L. (1942). Linguistics and reading. Elementary English Review, 19(1), 125-130.

Bozorgian, H., \& Pillay, H. (2013). Enhancing Foreign Language Learning through Listening Strategies Delivered in L1: An Experimental Study. International Journal of Instruction, 6(1), 105-122.

Brantmeier, C. (2002). The effect of passage content on second language reading comprehension by gender across instruction levels. The Journal of Teaching Language Skills, 4(1), 136-151.

Brown, A., \& Palincsar, A. (1989). Guided cooperative learning and individual acquisition. In L. B. Resnil (Ed.). Knowing, learning, and instruction: Essays in honor of Robert Glaser (pp. 393-410). University of Illinois at Urbana-Champaign Annemarie S. Palincsar Michigan State University

Brown, D. H. (2000). Principles of language learning \& teaching. (4th Ed.). New York: Longman.

Bruner, J. (1966). Toward a Theory of Instruction, Cambridge, Massachusetts: Harvard University Press.

Bruner, J. S. (1960). The process of education. Cambridge, MA: Harvard University Press. 
Carrell, P. L. (1985). Facilitating ESL reading by teaching text structure. TESOL Quartely, 19(2), 727-757. http://dx.doi.org/10.2307/3586673

Carrell, P. L. (1989). Metacognitive awareness and second language reading. TESOL Quarterly, 73(2), 121-134. http://dx.doi.org/10.1111/j.1540-4781.1989.tb02534.x

Carrell, P. L., Pharis, B. G., \& Liberto, J. G. (1989). Metacognitive strategy training for ESL reading. TESOL Quarterly, 20(3), 463-494. http://dx.doi.org/10.2307/3587536

Davis, B. G. (1999). Cooperative learning: Students working in small groups. Speaking of Teaching. Stanford University Newsletter on Teaching. 10(2), 1-24.

Davis, D., S. (2010). A meta-analysis of comprehension strategy instruction for upper elementary and middle school students. Unpublished Ph.D. dissertation. Vanderbilt University, America.

Dreyer, C., \& Nel, C. (2003). Teaching reading strategies and reading comprehension within a technology-enhanced learning environment. Available on http//www.elsevier.com.System, 31 (3), 349-65.

Duffy, G. (1993). Rethinking strategy instruction: Four teachers' development and their low achievers' understandings. Elementary School Journal, 93(3), 231-247. http://dx.doi.org/10.1086/461724

Fries, C. C. (1963). Linguistics and reading. New York: Holt, Rinehart \& Winston.

Gillies, R. M., \& Ashman, A. F. (2000). The effects of cooperative learning on students with learning difficulties in the lower elementary school. Journal of Special Education, 34(1), 19-27. http://dx.doi.org/10.1177/002246690003400102

Gladwin, R. F., \& Stepp-Greany, J. (2008). An interactive, instructor-supported reading approach vs. traditional reading instruction in Spanish. Foreign Language Annals, 41(4), 687-701. http://dx.doi.org/10.1111/j.1944-9720.2008.tb03325.x

Goodman, K. (1967). Reading: A psycholinguistic guessing game. Journal of the Reading Specialist, 6 (4), 126-35. http://dx.doi.org/10.1080/19388076709556976

Gorjian, B., Pazhakh, A. R., \& Naghizadeh, M. (2012). Comparative study of conjunctive adverbials (CAs) in native researchers' (NRs) and nonnative researchers' (NNRs) experimental articles. Advances in Asian Social Science, 1(2), 224-247.

Grundman, J. (2002). Cooperative Learning in an English as a Second Language. Retrieved from www.hamline.edu.

Harmer, J. (2011). How to Teach Writing. Harlow: Pearson Education Limited.

Hong-Nam, K., \& Leavell, A. G. (2006). Language learning strategies of ESL students in an intensive English learning context. System, 34(3), 399-415. Extracted from http//www.elsevier.com http://dx.doi.org/10.1016/j.system.2006.02.002 


\section{Al Macrothink}

Journal of Studies in Education

ISSN 2162-6952

2016, Vol. 6, No. 4

Hosseini, E., Sarfallah, S., Bakhshipour, F., \& Dolatabadi, H. R. (2012). Exploring the Relationship between Critical Thinking, Reading Comprehension, and Reading Strategies of Iranian EFL Readers World Applied Sciences Journal, 17 (10). 1356-1364.

Inhelder, B., \& Piaget, J. (1958). The Growth of Logical Thinking from Childhood to Adolescence. Basic Books, New York, NY.

Jacobs, G. M., Dufon, P., \& Hong, F. C. (1994). L1 and L2 vocabulary glossesinL2readingpassages: Their effectiveness for increasing comprehension and vocabulary knowledge. Journal of Research in Reading, 17(1), 19-28.

Janzen, J. (1996). Teaching strategic reading. TESOL Journal, 6(1), 6-9. http://dx.doi.org/10.1017/CBO9780511667190.040

Jia, G. (2003). The acquisition of the English plural morpheme by native Mandarin Chinesespeaking children. Journal of Speech, Language and Hearing Research, 46(2), 1297-1311. http://dx.doi.org/10.1044/1092-4388(2003/101)

Johnson, K. E. (1994). The emerging beliefs and instructional practices of preservice English as a second language teachers. Teaching and Teacher Education, 10(4), 439-52. http://dx.doi.org/10.1016/0742-051X(94)90024-8

Johnson, D. W., \& Johnson, R. T. (1991). Learning Together and Alone: Cooperative, Competitive, and Individualistic (3rdEdition). Englewood Cliffs, NJ: Prentice Hall.

Johnson, D. W., Johnson, R. T., \& Smith, K. A. (1998). Cooperative learning returns to college. Change, 30 (4), 26-35.

Johnson, D., \& Johnson, R., (1994). Learning together and alone, cooperative, competitive, and individualistic learning. Needham Heights, MA: Prentice Hall.

Johnson, D. W., \& Johnson, R. T. (1992). Advanced cooperative learning. Edina, MN: Interaction Books.

Jacobs, G. M., Crookall, D., \& Thiyaragarajali, R. (1997). The evolution of group activities in ELT coursebooks. Folio, 4(2), 21-24.

Kagan, S. (2014). About Kagan Publishing \& Professional Development. Kagan Online. Retrieved from http://www.kaganonline.com/about_us.php

Kazemi, M. (2012). The effect of Jigsaw technique on the learners' reading achievement: The case of English as L2. The Modern Journal of Applied Linguistics, 5(3), 170-184.

Keefe, J. W. (1979). Learning style: An overview. In J. W. Keefe (Ed.), Student learning styles: Diagnosing and prescribing programs (pp. 1-17). Reston, VA: National Association of Secondary School Principals.

Khosravi, A. A. (2000). The effect of scanning and skimming on the rate of and reading comprehension of Iranian EFL learners. Master thesis, Shiraz University, Iran. 


\section{Macrothink}

Journal of Studies in Education

ISSN 2162-6952

2016, Vol. 6, No. 4

Langer, J. A., \& Allington, R. L. (1992). Curriculum research in writing and reading. In P. W. Jackson (Ed.), Handbook of research on curriculum (pp. 687-725). New York: Macmillan.

Lantolf, J. (2006). Language competence: Implications for applied linguistics -A sociocultural perspective. Applied Linguistics, 2(7), 717-728.

Law, Y. K. (2011). The effects of cooperative learning on enhancing Hong-Kong fifth graders' achievement goals, autonomous motivation and reading proficiency. Journal of Research in Reading, 34(4), 402-425.

Liao, H. C., \& Oescher, J. (2009). Does cooperative learning really enhance self-efficacy and task value of English grammar learners? Journal of Education and Psychology, 32(3), 24-54.

Madhumathi, P., \& Ghosh, A. (2012). Awareness of reading strategy use of Indian ESL students and the relationship with reading comprehension achievement. English Language Teaching, 5(12).

McGroarty, M. (1993). Cooperative learning and second language acquisition. In D.D. Holt (Ed.), Cooperative learning: A response to linguistic and cultural diversity (pp. 19-46). McHenry, IL: Center for Applied Linguistics and Delta systems.

Mehrpour, S., Sadighi, F., \& Bagheri, Z. (2012). Teaching reading comprehension strategies to Iranian EFL pre-university students. The Journal of Teaching Lnguage Skills, 4 (1), 107-139.

Meteetham, P. (2001). Case study of cooperative learning by using jigsaw technique with second year English major students at Naresuan University. M.A. Dissertation, Mahidol University.

Mirzaei, L. (2012) The Effect of Cooperative Learning Techniques, Eleboration, Construction, and Question raising on Improving EFL learners' Reading Comprehension. A thesis from Khouzestan, Iran, Ahwaz Azad Branch.

Mokhtari, K., \& Reichard, C. A. (2002). Assessing students' metacognitive awareness of reading strategies. Journal of educational psychology, 94(2), 249. http://dx.doi.org/10.1037/0022-0663.94.2.249

Mokhtari, K., \& Reichard, C. (2004). Investigating the strategic reading process of first and second language readers in two different cultural contexts. System, 32(2), 379-394.

Mokhtari, K., \& Sheorey, R., (2002). Measuring ESL students' awareness of reading strategies. Journal of Development Education 25(3), 2-10.

Momtaz, E., \& Garner, M. (2010). Does collaborative learning improve EFL students' reading comprehension. Journal of linguistics and language teaching, 1(1), 15-36.

Naiman, N. (1978). The good language learner. Toronto: Ontario Institute for Studies in Education. 
National Reading Panel. (2000). Teaching children to read: An evidence-based assessment of the scientific research literature on reading and its implications for reading instruction. Washington, DC: National Institute of Child Health \& Human Development.

Nunan, D. (1998). Second language teaching and learning. Boston: Heinle \& Heinle Publishers.

O'Keefe, M. (1997). Predictors of dating violence among high school students. Journal of Interpersonal Violence, 12(6), 546-568.

Oxford, R., \& Nyikos, M. (1989). Variables affecting the choice of language learning strategies by university students. The Modern Language Journal, 73(2), 291-300. http://dx.doi.org/10.1111/j.1540-4781.1989.tb06367.x

Oxford, R. (1990). Language learning strategies: What every teacher should know. Boston: Heinle \& Heinle.

Palincsar, A. S., \& Brown, A. L. (1984). Reciprocal teaching of comprehension-fostering and comprehension-monitoring activities. Cognition and Instruction, 1(2), 117-175.

Pearson, P. D., \& Fielding, L. (1991). Comprehension instruction. In P. Pearson, R. Barr, M. Kamil, \& P. Mosenthal (Eds.), Handbook of reading research (pp. 815-860). White Plains, NY: Longman.

Pressley, M., \& El, Dinary, V. (1992). Cognitive strategy instruction that really improves Children's academic performance. Cambridge, MA: Brockline Books.

Pressley, M. (2000). What should comprehension instruction be the instruction of? In M.L. Kamil, P.B. Mosenthal, P.D. Pearson and R. Barr (eds), Handbook of reading research, 3(2), 545-561.

Pressley, M. (2006). Reading instruction that works: the case for balanced teaching. New York: Guilford Press. ISBN 1-59385-229-0.OCLC61229782.

Rahvard, Z. J. (2010). Cooperative learning strategies and reading comprehension. California Linguistic Notes, 35(2), 1-15.

Richards, J. C., \& Rodgers, T. (2000). Approached and methods in language teaching. (2nded.). New York: Cambridge University Press

Rubin, J. (1975). What the good language learner can teach us. TESOL Quarterly, 9 (1), 41-51. http://dx.doi.org/10.2307/3586011

Salataci, R., \& Akyel, A. (2002). Possible effects of strategy instruction in L1 \& L2 reading. Reading in Foreign Language, 14 (1), 234-255.

Sasaki, M. (2000). Toward an empirical model of EFL writing processes: an exploratory study. Journal of Second Language Writing, 9(3), 259-91. http://dx.doi.org/10.1016/S1060-3743(00)00028-X 
Shokrpour, N., \& Fotovatian, S. (2009). Effects of consciousness raising of metacognitive strategies on EFL students' reading comprehension. ITL - International Journal of Applied Linguistics, 157(1), 75-92. http://dx.doi.org/10.2143/ITL.157.0.2042588

Sittilert, W. (1994). Effects of cooperative integrated reading and composition (CIRC) on English reading comprehension and opinions about classroom atmosphere of mathayomsuksa five students. M.A. Dissertation, Chiangmai University.

Slavin, R. E. (1995). Cooperative learning: Theory, research and practice. (2nd ed). Boston: Allyn and Bacon.

Slavin, R. (1987). Co-operative learning. The Elementary School Journal, 88.

Stern, H. (1975). What can we learn from the good language learner. The Canadian Modern Language Review, 31(3), 304-318.

Suh, J. S. (2009). Reading concepts in cooperative work by EFL college students. English Teaching, 64(2), 151-171.

Thompson, I., \& Rubin, J. (1996). Can strategy instruction improve listening comprehension?
Foreign
Language
Annals,
29
(3),
331-342.

http://dx.doi.org/10.1111/j.1944-9720.1996.tb01246.x

Ur, P. (1996). A Course in Language Teaching: Practice and Theory. Cambridge: Cambridge University Press.

Wright, M., \& Brown, P. (2006). Reading in a modern foreign language: exploring the potential benefits of reading strategy instruction. Language Learning Journal, 33(3), 22-33. http://dx.doi.org/10.1080/09571730685200071

Zoghi, M., Mustapha, R., \& Tg. Nor Rizan Mohd. Maasum, (2010). Collaborative strategic reading with university EFL learners. Journal of College Reading and Learning, 41(1), 67-94. http://dx.doi.org/10.1080/10790195.2010.10850336 